\title{
Ground improvement by vacuum consolidation - a review
}

1 Harry Griffin BA, BAI

Research Assistant, Department of Civil, Structural and Environmental Engineering, Trinity College Dublin, Dublin, Ireland
2 Brendan C. O'Kelly PhD, FTCD, CEng, CEnv, MICE Associate Professor, Department of Civil, Structural and Environmental Engineering, Trinity College Dublin, Dublin, Ireland

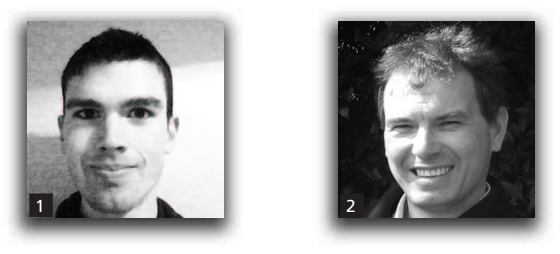

This paper presents a review of literature related to the vacuum consolidation ground improvement technique, focusing on issues affecting efficiency of performance and the application of the technique in peaty ground. Although it is now widely considered to be effective for reducing post-construction settlement, studies on vacuum consolidation in peat have, to date, mostly been limited to field trials. This paper offers an overview of the development and theory behind the technique. Issues affecting the efficiency of vacuum systems and recent advances in predicting the ground response to vacuum preloading are described. The application of the technique in peaty soils is investigated; an overview is also provided of some geotechnical properties that distinguish peat from soft mineral soils, highlighting lessons learned from relevant case studies.

\section{Notation}

a positive integer representing differential settlement

$c_{\mathrm{vh}}$ coefficient of consolidation for horizontal flow condition

$I_{\mathrm{r}} \quad$ rigidity index

$k \quad$ factor dependent on PVD installation depth and loading period

$k_{\mathrm{h}} \quad$ horizontal permeability for undisturbed soil

$k_{\mathrm{s}} \quad$ horizontal permeability for disturbed soil

$k_{\mathrm{v}} \quad$ vertical permeability for undisturbed soil

$n$ diametrical ratio of soil element to central prefabricated vertical drain

OCR over-consolidation ratio

$p \quad$ mean effective stress

$p_{\text {a }} \quad$ atmospheric pressure

$r \quad$ smear zone radius

$r_{\mathrm{m}} \quad$ equivalent elliptical radius of mandrel

$U_{\mathrm{r}} \quad$ average degree of consolidation due to radial drainage

$u \quad$ pore water pressure

$\gamma^{\mathrm{p}} \quad$ plastic shear strain

$\varepsilon \quad$ engineering strain

$\eta \quad$ efficiency

$\sigma \quad$ total stress

$\sigma^{\prime} \quad$ effective stress

\section{Introduction}

\subsection{Background}

Soils having poor engineering characteristics now demand more consideration in construction activity, especially in regions where good quality ground (i.e. with adequate bearing capacity and low compressibility) is in short supply. Surcharge preloading with prefabricated vertical drains (PVDs) is one of the most popular techniques for ground improvement involving soft soils (Beales and O'Kelly, 2008; Indraratna et al., 2010a). The inclusion of the PVDs into the ground artificially reduces the drainage path length, thereby speeding up the consolidation process which may otherwise take many years to achieve substantial completion for soft soil deposits (Bo et al., 2003; Saowapakpiboon et al., 2010). However, the surcharge loading required to ensure such deposits undergo acceptably low amounts of settlement post-construction are often so large that, in maintaining an adequate factor of safety against slope instability, it may prove rather time consuming to apply the necessary fill layers. In this regard, use of the vacuum consolidation technique in conjunction with surcharge preloading and PVDs can enhance the efficiency of ground improvement works (Chu et al., 2000; Indraratna, 2010; Mesri and Khan, 2012). The vacuum preloading technique, originally proposed by Kjellman (1952), has over the past three decades evolved to become a viable, more cost-effective solution for ground improvement projects worldwide (see Table 1). This has been largely due to improvements in geosynthetic/PVD and vacuum pump technology.

Vacuum consolidation usually involves applying a vacuum pressure into ground that has been protected from pressure losses at its surface by a sealing membrane (Figure 1). The vacuum pump produces a negative pressure (with respect to atmospheric pressure) in the permeable soil cushion, located immediately beneath the sealing membrane, and along PVDs installed within 


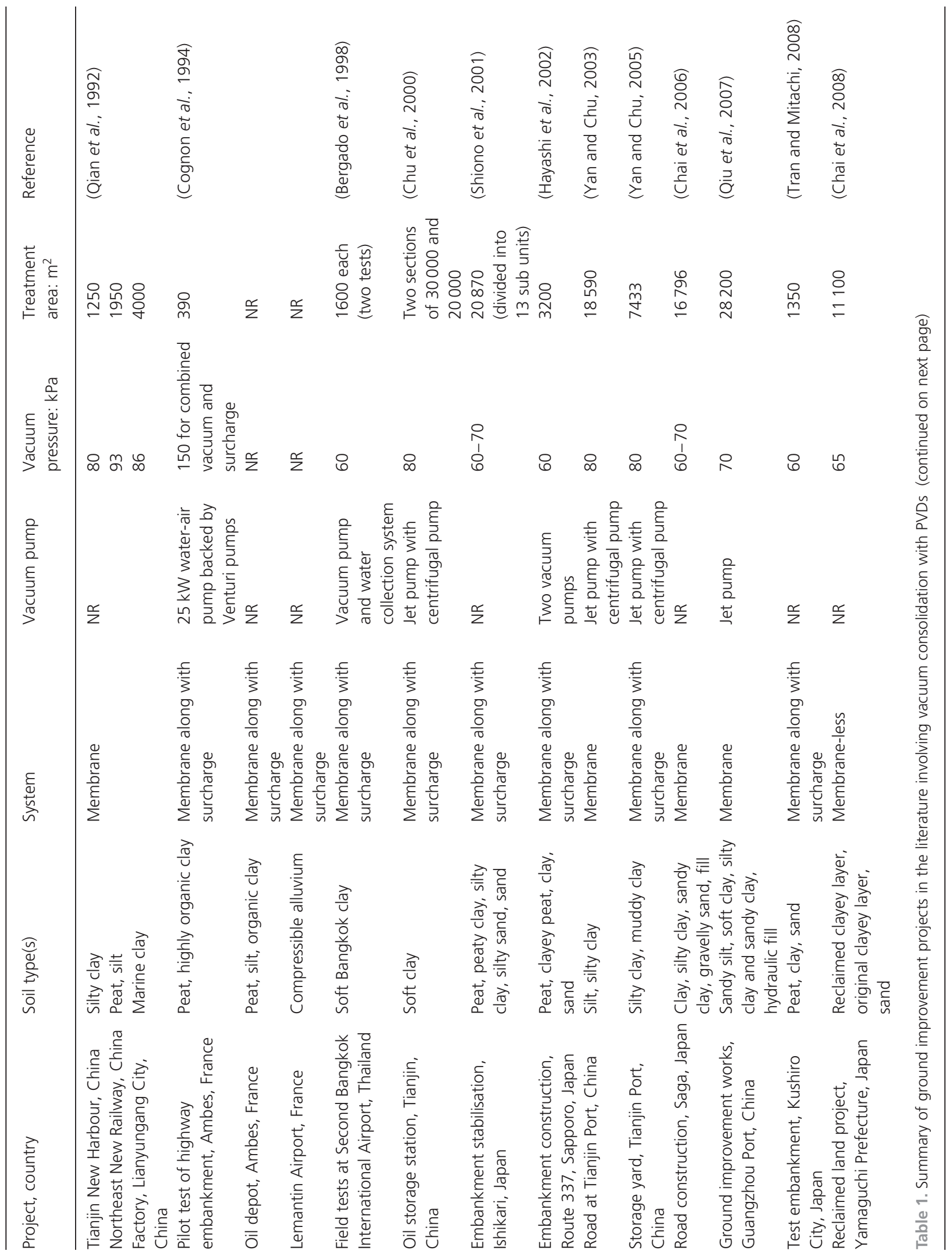


the ground under treatment. Vacuum pressures as high as $90 \mathrm{kPa}$ may be achieved in practice for soft clays, although a value of $80 \mathrm{kPa}$ is typically considered for design (Chu et al., 2008).

\subsection{Theory}

The surcharge and vacuum preloading mechanisms can be explained using a spring analogy (Figure 2). Since geotechnical analysis is usually based on mean effective stress $\left(p^{\prime}\right)$, atmospheric pressure $\left(p_{\mathrm{a}}\right)$ tends to be disregarded in stress calculations. However, it must be considered for an understanding of the theory underlying vacuum consolidation. When a vacuum pressure is applied, the total stress remains the same but a decrease in the pore pressure by $p_{\mathrm{a}}$ causes a corresponding increase in the mean effective stress $\left(\Delta p^{\prime}\right)$ to occur. Accounting for vacuum pump efficiency $(\eta)$, normally $70-80 \%$ of atmospheric pressure (Chu et al., 2008)

1. $\Delta p^{\prime}=\eta p_{\mathrm{a}}$

The superposition principle can be applied when surcharging is combined with vacuum preloading; that is the resulting pore pressure equals the excess pore water pressure generated by the surcharge plus the pore pressure reduction induced by vacuum preloading. Hence the maximum induced pore water pressure is smaller, compared with surcharge preloading alone.

Choosing vacuum-assisted preloading over surcharge preloading alone can potentially reduce the cost of ground improvement works by $30 \%$ (TPEI, 1995; Yan and Chu, 2003). There is also a much reduced risk of slope instability occurring. The vacuum technique is considered to be environmentally sustainable compared to the alternatives, since (Indraratna et al., 2010c, 2012a)

- compared with surcharging alone, reduced surcharge loads for vacuum-assisted preloading means less fill material must be transported to site

- chemical residues are not introduced and left in the soil, although the PVDs remain in the ground post-treatment

- carbon emissions are approximately 30 times smaller compared with an equivalent pile foundation solution

- associated noise levels are acceptable; for example, in contrast to works involving driven piles.

\subsection{PVDs}

PVDs serve a dual purpose during vacuum consolidation in that they aid in the balanced distribution of vacuum pressure over the soil treatment depth while also discharging extracted pore water up to the permeable soil cushion at ground surface level (Chu et al., 2008). As they have become cheaper, flexible PVDs have generally replaced sand drains and granular piles (Dam et al., 2006; Indraratna, 2010). Although dynamic methods of PVD installation such as vibrating or drop hammer techniques are sometimes used, static methods are generally preferable since they produce less disturbance to the surrounding soil (Ghandehar- 


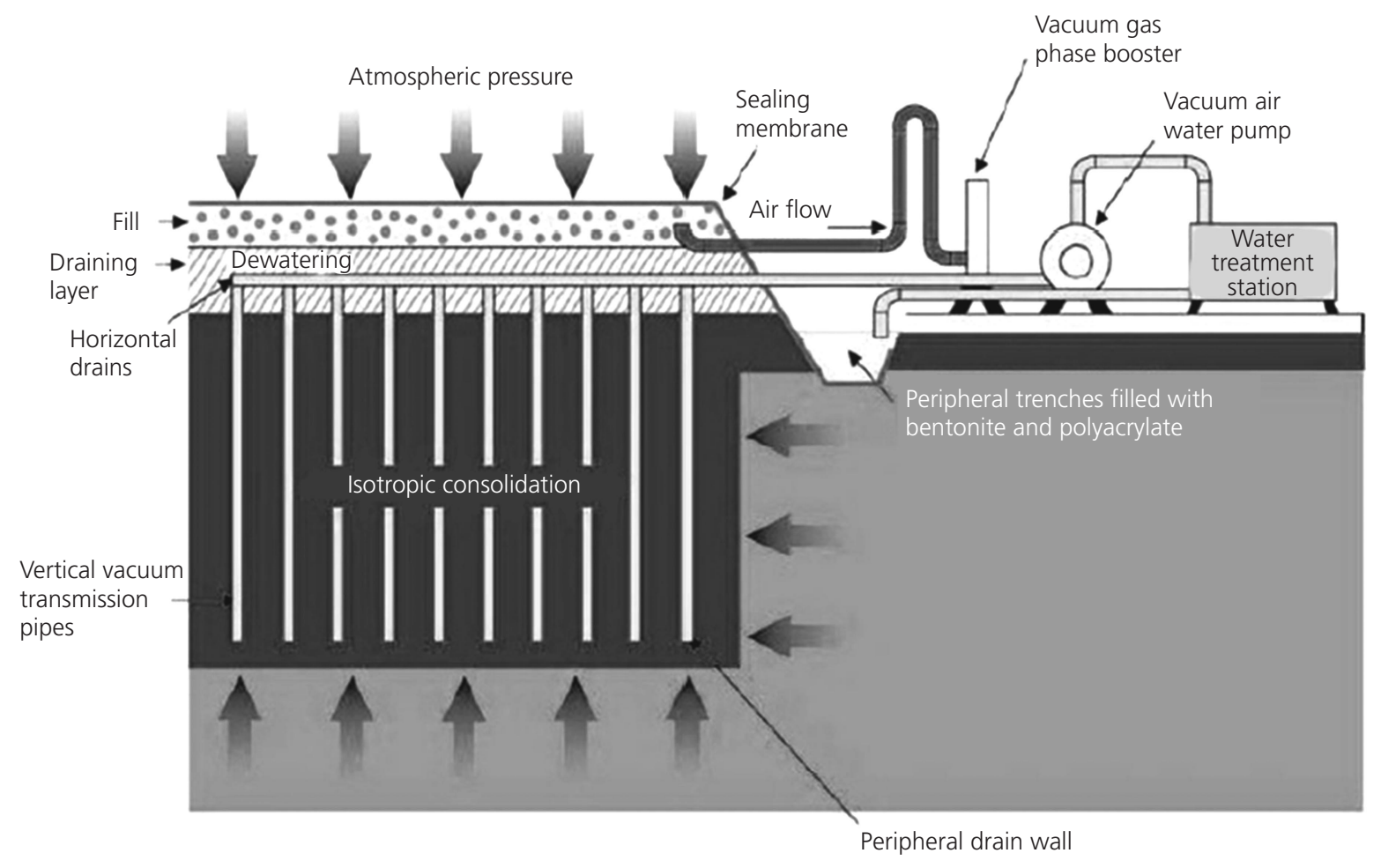

Figure 1. Schematic diagram of typical membrane vacuum consolidation system (Masse et al., 2001)

ioon et al., 2010). Indraratna et al. (2011) observed that band PVDs and circular PVDs exhibited similar performance in areas under embankment surcharge alone. However, in vacuum preloaded areas, circular PVDs were found to produce faster consolidation rates, most likely due to their ability to transfer vacuum pressures to great depths more effectively.

Design charts for vertical drains were developed by Rujikiatkamjorn and Indraratna (2007) in order to estimate an appropriate drain spacing, considering a larger range of soil properties and drain installation patterns. In plan, vertical drains are generally arranged in either a square or triangular grid pattern. Drain spacing of $1.2-1.3 \mathrm{~m}$ is considered adequate for design in highly compressible clay, with a reduction in the consolidation rate possible for drains placed at closer spacing on account of the intersection of smear zones (Indraratna et al., 2011). The design drain spacing is a function of both the vertical and horizontal drainage consolidation properties and effective drainage lengths and also the time period targeted to achieve the desired average degree of consolidation under combined vertical and radial drainage.

\subsection{Field investigation}

Table 1 presents a summary of vacuum consolidation projects reported in the literature over the past two decades, with a typical set-up for a membrane vacuum consolidation system shown in Figure 1.
When vacuum consolidation has to be performed over an extensive area, the installation of the drain system can become a significant challenge. This occurs because the vacuum treatment would need to be performed consecutively for different sub-areas, although this approach leads to inefficiencies (Chu et al., 2008). This challenge may be overcome by connecting the vacuum line directly to each individual PVD using a tubing system, such as that proposed by Seah (2006) (Figure 3). Hence a sand blanket and sealing membrane are not required since the connections from the top of the PVDs to the vacuum line are completely sealed. However, unless the system provides an airtight condition for the entire treatment area, the efficiency may be quite low, with vacuum pressures conceivably no greater than $50 \mathrm{kPa}$ (Seah, 2006). Inter-bedded, more permeable layers can also produce some practical problems. Wrapping an impermeable plastic sleeve around each PVD, over the depth of the more permeable layer, is one solution, but the adoption of this approach in practice requires precise knowledge of the subsoil strata (Chu et al., 2008).

Field monitoring usually encompasses measurements of the pore water pressure and the vertical and lateral displacements at different soil depths. Whether the average degree of consolidation is evaluated based on settlement or pore water pressure data is relevant and should be made clear in design work (Chu and Yan, 2005b). The average degree of consolidation achieved can often be underestimated because instruments monitoring the pore water 

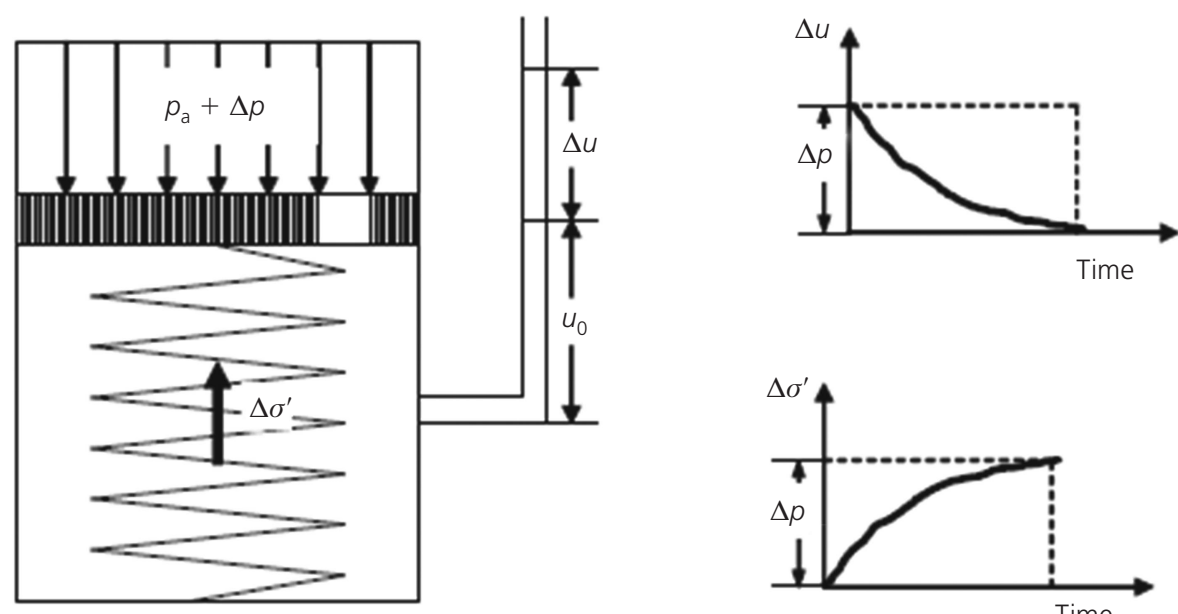

$$
\begin{gathered}
u_{0}=p_{\mathrm{a}} \\
\Delta \sigma^{\prime}=p_{\mathrm{a}}+\Delta p-\left(u_{0}+\Delta u\right)=\Delta p-\Delta u
\end{gathered}
$$

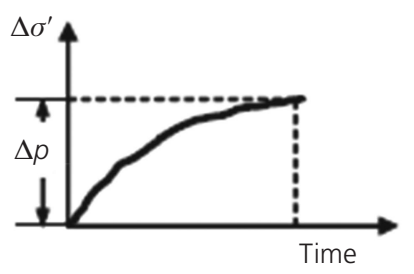

(a)

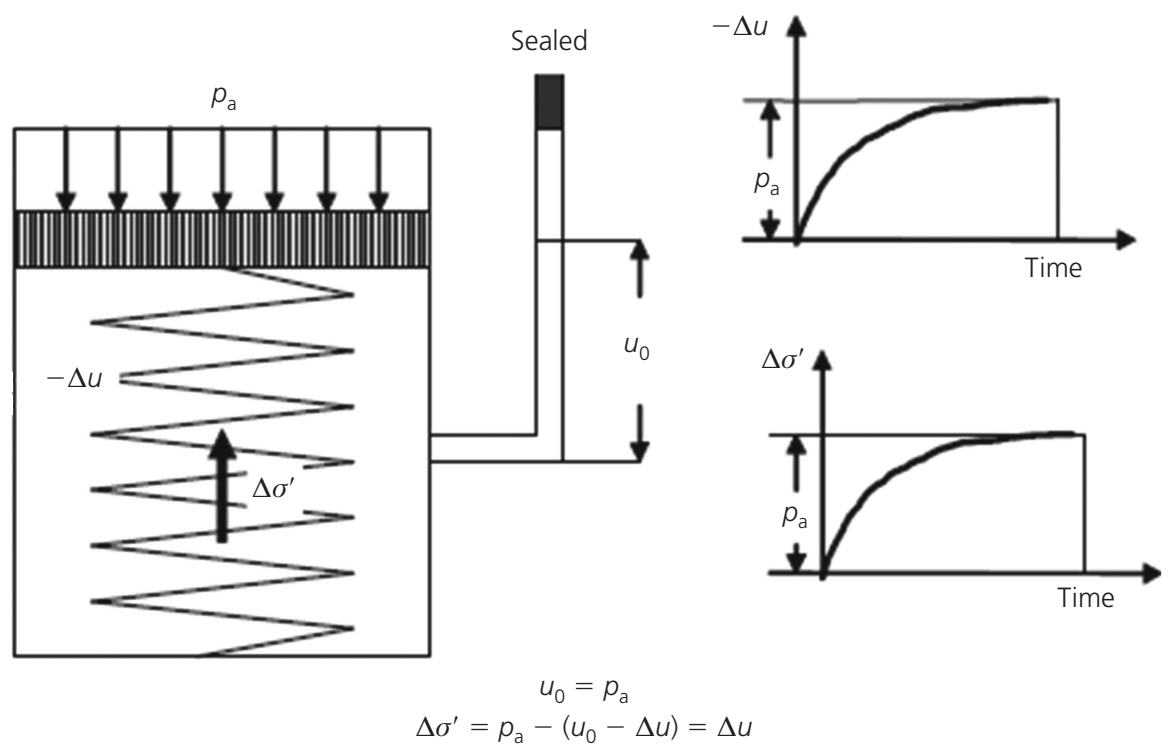

(b)

Figure 2. Spring and piston analogy of consolidation response (Chu and Yan, 2005a): (a) surcharge pressure, $\Delta p$; (b) vacuum pressure, $-\Delta u$

pressure response are typically installed where the highest values are likely to occur (Chu et al., 2008). For instance, pore pressure transducers are usually installed equidistant from neighbouring PVDs.

\section{Factors affecting PVD performance}

Prefabricated vertical drain efficiency is influenced by a number of factors including smear effects and well resistance. The development of an unsaturated zone close to the PVD following mandrel withdrawal may also reduce the pore pressure dissipation rate within the unit cell, until such time as the soil becomes more saturated again. Discrepancies between prediction and perform- ance of the vacuum consolidation technique arise from difficulties in predicting the impact of the above effects, along with incorrect assumptions regarding soil behaviour and the vacuum pressure distribution achieved against depth over the treatment area.

\subsection{Vacuum pressure distribution}

Masse et al. (2001) reported that, in theory, vacuum pressure should not vary with depth and should only be limited by the depth to which the vertical drains can be installed. However, a common concern is that vacuum pressures can only be effectively applied to a depth of about $10 \mathrm{~m}$ below ground level (bgl), regardless of drain length. For instance, Bergado et al. (1998) 


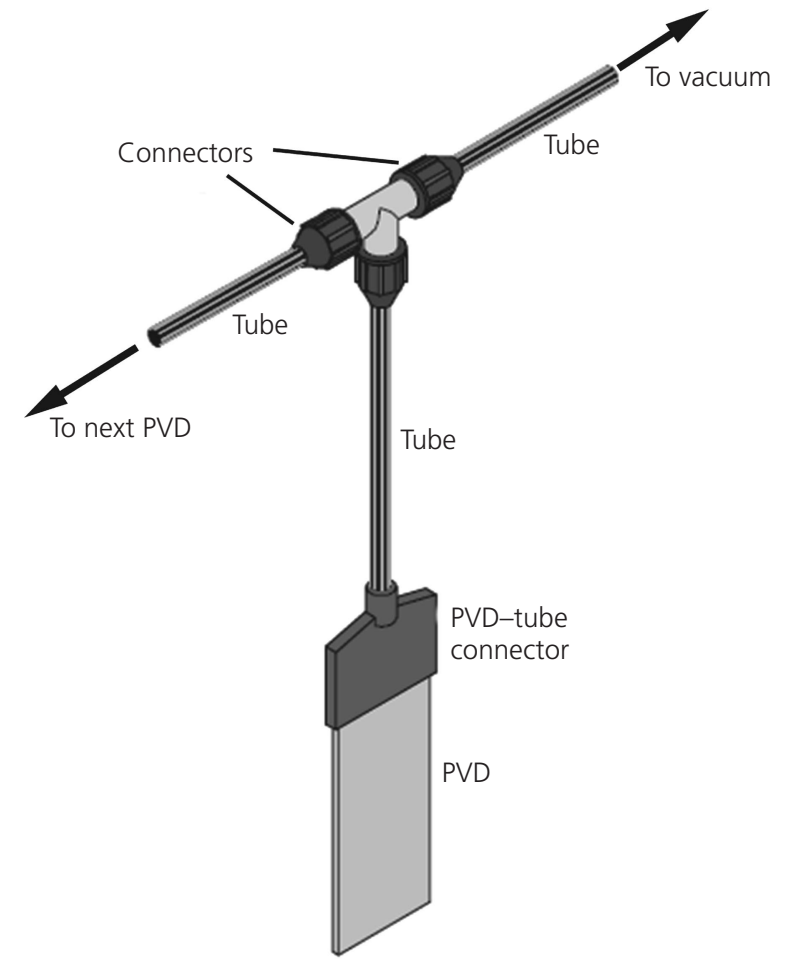

Figure 3. Individual PVD and tubing arrangement for vacuum consolidation (Seah, 2006). Reproduced by permission of Southeast Asian Geotechnical Society

observed that the vacuum pressure achieved at $15 \mathrm{~m} \mathrm{bgl}$ was only $25 \%$ of that applied at the ground surface, even though the PVDs had extended to this depth. Choa (1989) noted that vacuum consolidation diminished in its effect at $14 \mathrm{~m} \mathrm{bgl}$, despite the fact that the vertical drains had extended to $20 \mathrm{~m}$ bgl. However, as the technology advances, higher vacuum pressures and greater treatment depths may be achieved. Chu et al. (2000) reported that for a $20 \mathrm{~m}$ deep very soft clay deposit, the applied vacuum pressure was fully developed to $14 \mathrm{~m} \mathrm{bgl}$, with approximately $80 \%$ achieved at greater depths. However, the uniformity of the vacuum may also be affected if the soil profile is highly stratified (Mesri and Khan, 2012).

For deposits open to two-way vertical drainage, the PVDs should only partially penetrate the layer under treatment in order to prevent vacuum pressure loss by way of the bottom drainage boundary (Chai et al., 2005). Also, in the case of deep, soft soil deposits open to one-way vertical drainage, it may not be feasible to install PVDs over the full depth. In this case, Chai et al. (2009) reported that there may be an optimum depth ratio of PVD installation to base of soil layer under treatment for which the same average degree of consolidation may be achieved as for a fully penetrating PVD. However, partial penetration makes anchoring of PVDs during installation more difficult. A larger anchor plate is required to secure the base position of the PVD within soft soils, an action that causes significant soil disturbance.
Using numerical analysis, Indraratna and Rujikiatkamjorn (2008) studied the effects of partially penetrating drains on the average degree of consolidation achievable. They found that reducing the drain length below $90 \%$ of the compressible layer thickness significantly affected the consolidation rate. Only a small number of approximate or semi-analytical solutions exist for determining the average degree of consolidation in a deposit partially penetrated by PVDs, although a more accurate and practical solution has been recently proposed by Ong et al. (2012).

\subsection{Smear zone effects}

Compared with undisturbed soil, reductions in pore pressure and increases in shear strength under vacuum and (or) surcharge preloading tend to be greater within the smear zone around the PVD (Bo et al., 1998; Saowapakpiboon et al., 2011). Smear effects are determined by the extent of soil disturbance and the ratio of horizontal permeability within the undisturbed soil to that within the smear zone $\left(k_{\mathrm{h}} / k_{\mathrm{s}}\right)$; this ratio is dependent on soil sensitivity and macro fabric (Indraratna et al., 2010c).

\subsubsection{Size of smear zone}

Studies on PVD installation in vacuum-consolidated soils have produced different estimates for the smear zone radius, usually ranging from a factor of 1.5 (Sharma and Xiao, 2000) to slightly more than 3 times the effective radius of the drain (Ghandeharioon et al., 2010, 2012). Sathananthan and Indraratna (2006) predicted that the average radius of the smear zone would be approximately 3.5 times the equivalent radius of the mandrel. The concept of overlapping smear zones may explain why consolidation rates generally do not increase below a certain value of drain spacing. The extent of smear effects may be reduced by using mandrels having different shapes and smaller cross-sectional area (Bergado et al., 1991).

Ghandeharioon et al. (2010) proposed that PVD installation in soft clays using a rectangular steel mandrel would produce an elliptical cavity expansion, with a concentric progression in the horizontal plane. The affected zone is characterised by the plastic shear strain $\left(\gamma^{\mathrm{p}}\right)$, with the ratio of $\gamma^{\mathrm{p}}$ to rigidity index $\left(I_{\mathrm{r}}\right)$ often providing a good indicator of the extent of the smear zone. Hence, in practice, these soil parameters can be used to approximate the extent of the smear zone, avoiding the need for sophisticated large-scale trials. Based on the range of strains identified, as illustrated in Figure 4, the smear zone radius was determined as 3.07 times $r_{\mathrm{m}}$; where $\gamma^{\mathrm{p}} / I_{\mathrm{r}}=0.135 \%$ is the average value corresponding to the smear zone boundary.

One of the most common procedures used for simulating soil behaviour in response to mandrel installation is an incrementaldisplacement finite-element (FE) method, using either small- or large-strain analysis. Ghandeharioon et al. (2012) developed a modified oedometer and mandrel-driving machine to study the soil response to PVD installation. Large displacements experienced by soft clay in response to mandrel-driven PVD installation necessitate the use of a large strain formulation for the frictional 


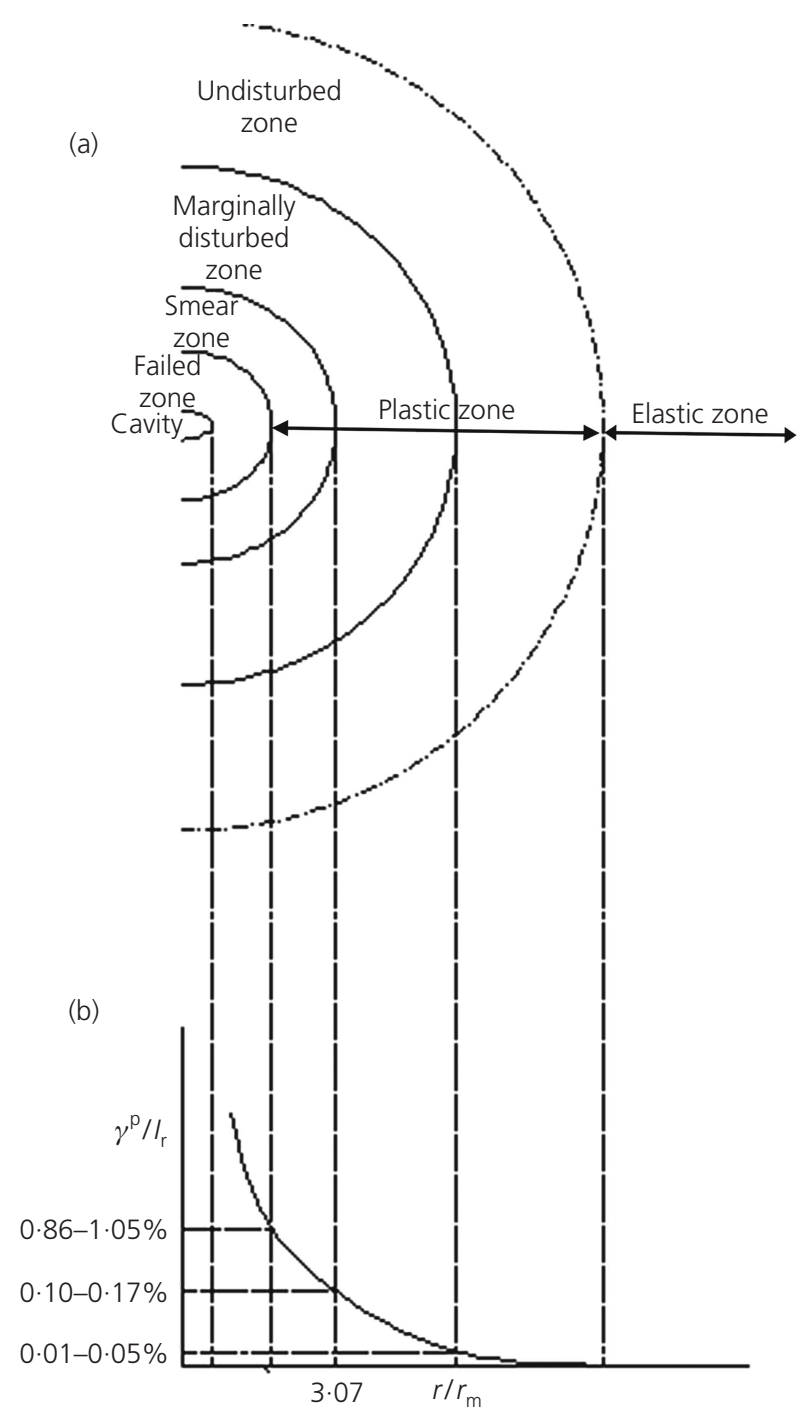

Figure 4. (a) Distribution pattern for different soil zones surrounding PVD. (b) Relationship of plastic shear strain to rigidity index ratio plotted against ratio of radial distance to equivalent elliptical radius of mandrel (adapted from Ghandeharioon et al., 2010)

contact between the soil and mandrel. Their results showed that for a given soil type and installation rate, in situ effective stresses increased as the extent of the smear zone reduced. They also found that the extent of the smear zone decreased as the soil over-consolidation ratio (OCR) increased.

\subsubsection{Permeability and smear}

For soft clays, the $k_{\mathrm{h}} / k_{\mathrm{s}}$ ratio is generally in the range $1-8$ (Rujikiatkamjorn and Indraratna, 2007). Saowapakpiboon et al. (2011) performed a large-scale oedometer study of soft Bangkok clay improved by surcharge preloading and PVDs, both with and without application of vacuum. Although the final settlement was the same for both scenarios, the vacuum-surcharge combination was found to produce a much quicker settlement rate. Compared with surcharge alone, the vacuum-surcharge combination also produced a greater reduction in water content and higher hydraulic conductivity within the smear zone, resulting in a $10 \%$ decrease in the $k_{\mathrm{h}} / k_{\mathrm{s}}$ ratio from 3.0 to $2 \cdot 7$. They also found that the coefficient of primary consolidation for the horizontal flow direction $\left(c_{\mathrm{vh}}\right)$ was $16 \%$ greater overall for the vacuum-surcharge combination. From a sensitivity analysis using the FE method, they found that the magnitude of predicted settlement increased as the $k_{\mathrm{h}} / k_{\mathrm{s}}$ ratio decreased. Saowapakpiboon et al. (2010) performed a similar study using soil from the same deposit and under the same loading conditions. Again, the final settlement achieved by both preloading techniques was the same, although the use of vacuum preloading was found to accelerate the consolidation process compared with surcharge alone. The hydraulic conductivity within the smear zone was also higher, producing $c_{\mathrm{vh}}$ values $70 \%$ greater and $k_{\mathrm{h}} / k_{\mathrm{s}}$ ratio values $7 \%$ lower compared with surcharge alone.

\subsection{Well resistance}

Water flowing upwards along the vertical drain may be impeded by well resistance, which is higher for drains installed to great depths and of limited discharge capacity. Ideal drain theory, often used in such analysis, assumes the drain permeability to be infinitely high in relation to the permeability of the surrounding soil and that the pore water can drain into the well (PVD) without meeting any resistance (Deng et al., 2013). However, for more highly permeable ground, the rate at which pore water under excess pressure wants to enter the PVD is greater than its discharge capacity, preventing free-flow conditions from occurring (Hansbo et al., 1981). Mesri and Khan (2012) asserted that the effect of well resistance should be considered in design, particularly for deep drain installations.

Well resistance manifests as clogging of drainage channels, reduction in drain cross-sectional area and also deformation of the PVDs themselves, all of which cause considerable reduction in discharge capacity. However, the influence of well resistance on consolidation rate has received relatively little attention, often resulting in an underestimation of the time period required to achieve the desired average degree of consolidation. Using a linearity assumption, Kim et al. (2011) simulated the influence of a time-dependent well resistance factor, producing good results but not a rigorous solution. Deng et al. (2013) assumed that the discharge capacity decreased exponentially with elapsed time. From a solution incorporating time-dependent well resistance, they concluded that the unit cell method (i.e. cylindrical element uniform soil cylinder with central PVD) tends to overestimate the consolidation rate because it assumes a fixed short-term discharge capacity. This discrepancy increases with increasing time during the consolidation process.

\subsection{Lateral displacement}

The lateral displacement of a soil element under vacuum consolidation depends on its relative depth below ground surface level and distance from neighbouring vertical drains. In the 
central area of the ground mass under treatment, each drain only affects the soil closest to that particular drain (i.e. no lateral displacement occurs) and the unit cell method applies (Masse et al., 2001). However, the influence of neighbouring drains on the soil response is significant nearer the perimeter of the area under treatment. In this region, surcharge loading alone induces shear stresses in the ground, which may cause outward lateral displacements (Figure 5(a)), potentially leading to shear failure. In contrast, vacuum consolidation alone induces inward lateral displacements (Figure 5(b)) since it introduces an isotropic consolidation pressure to the soil mass. Hence, under vacuum consolidation, surface tension cracks may develop around the perimeter of the treated soil area, but without the potential risk of shear failure occurring. Hence, for combined vacuum-surcharge preloading, the net lateral displacement can be reduced (Indraratna et al., 2011) and, in theory, prevented from occurring. For clays, a combination of $60 \%$ vacuum and $40 \%$ surcharge preloading stresses seems to maintain net lateral displacements of close to zero (Indraratna and Rujikiatkamjorn, 2008).

On the basis of tests using a modified hydraulic consolidation (Rowe cell) apparatus, Robinson et al. (2012) showed that deformation of a soil element under vacuum consolidation is

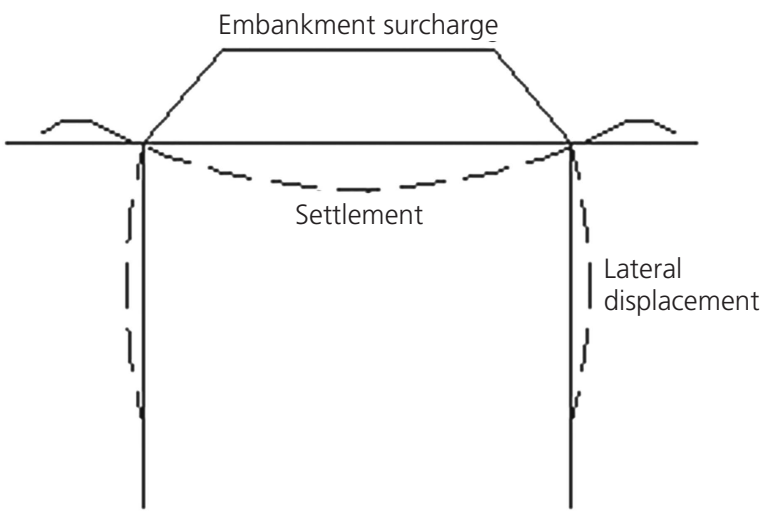

(a)

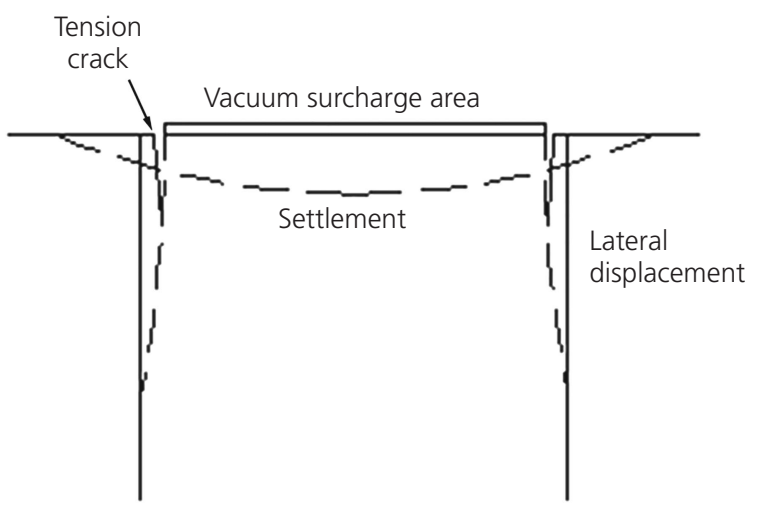

(b)

Figure 5. Lateral deformation of soil under (a) embankment surcharge and (b) vacuum consolidation isotropic and hence its vertical deformation is significantly less than for one-dimensional (1D) compression occurring under an applied vertical stress alone. This agrees with Chai et al. (2005), who found that if the stress applied to a soft soil is greater than its preconsolidation stress, the induced settlement is smaller for vacuum consolidation than for surcharging. An empirical method for estimating the lateral displacement profile against depth, on the basis that a relationship exists between lateral displacement at a particular depth and surface settlement, has been proposed by Mesri and Khan (2012). It confirms the conclusion of Ong and Chai (2011) that the amount of lateral displacement depends on the compressibility of the deposit in addition to the loading condition.

\section{Numerical analysis}

Mohamedelhassan and Shang (2002) proposed a 1D solution for consolidation under combined vacuum-surcharge preloading. This solution was modified by Indraratna et al. (2005) to include the effect of radial drainage allowed by PVDs. They also developed analytical solutions for the plane-strain condition of a single cell unit, following a conversion procedure from the axisymmetric condition, which was implemented in an FE model. A number of studies have presented three-dimensional (3D) solutions to radial consolidation problems but the majority still employ conversions to the plane-strain condition. This is mainly because the time required to compute a full plane-strain simulation is considerably reduced compared with a full $3 \mathrm{D}$ simulation (Indraratna and Redana, 2000; Indraratna et al., 2004). Rujikiatkamjorn and Indraratna (2007) proposed a comprehensive solution incorporating vertical and horizontal drainage and that also accounted for smear effects. Walker and Indraratna (2009) produced a more rigorous solution to the consolidation problem which can be applied to multi-layered deposits through the spectral method - a mesh-less approach involving a series of matrix operations. Indraratna et al. (2012a) subsequently proposed a modified solution, again using the spectral method, which accounts for variation in permeability with depth and produces average pore pressure values across single or multiple soil layers. Indraratna et al. (2012b) developed an analytical model for vacuum consolidation under axisymmetric and plane-strain conditions which simulates the consolidation of a unit cell incorporating a central PVD. This model invokes elliptical cavity expansion theory and takes into account smear effects, non-Darcian flow conditions and vacuum propagation along the PVD length. The conversion procedure, based on permeability and vacuum pressure transformations, ensures that settlement against loading period curves for two-dimensional (2D) and full 3D analyses are identical.

Unit cell analysis approaches are only of limited use in practice, however, since ground-improvement projects require installation of a large array of drains. As such, single drain analysis may only be applicable within the central area of a uniform deposit under vacuum-assisted preloading since it is reasonable to assume that negligible lateral displacement occurs here (Indraratna et al., 
2012a; Seah, 2006). However, the areas nearer the boundaries may undergo considerable lateral displacement (Indraratna et al., 2005). Indraratna et al. (2012a) proposed solving the multi-drain problem using an equivalent plane-strain FE model and applied it in analysing the ground response for construction of a new pier on reclaimed land at Tianjin Port, China. Chu et al. (2000) and Chu and Yan (2005b) have reported on this project in detail. Indraratna et al. (2012a) produced similar predictions of the ground settlement response from plane-strain and 3D FE analyses, which agreed with field measurements, although the reduction in pore pressure predicted by the $2 \mathrm{D}$ analysis was slightly higher during the initial 2-month consolidation period.

Similar observations were reported between measurements from a consolidometer apparatus and a 2D axisymmetric FE model presented by Saowapakpiboon et al. (2011). The simulations predicted the measured settlements quite accurately although simulated excess pore pressures were greater than measured values early on during the single load stage. Saowapakpiboon et al. (2010) used a 1D FE model to predict the settlement-time response for soft Bangkok clay, both with and without vacuum preloading. This model underpredicted settlement occurring early on during consolidation, although predictions for the final settlement were more accurate. Geng et al. (2012) presented a 2D numerical solution for soil having non-linear properties and also considering smear effects, well resistance and vertical and horizontal drainage. This solution showed that the average degree of consolidation computed in terms of measured pore water pressure was considerably less than that computed in terms of settlement.

Modelling accuracy can be improved further by eliminating approximations regarding the strain distribution pattern. $\mathrm{Wu}$ and $\mathrm{Hu}$ (2012) proposed a radius-related strain distribution method, as part of an axisymmetric model, which also assumed a linear decrease in vacuum pressure with increasing depth along the drain. Strain, $\varepsilon$, was related to smear zone radius, $r$, by

2. $\frac{\partial \varepsilon}{\partial t}=\frac{k}{r^{a}}$

where $k$ is a factor dependent only on PVD installation depth and loading period, $t$; $a$ is a positive integer representing differential settlement.

The equal strain hypothesis (i.e. 1D consolidation) applies when the value of $a$ equals zero. In the analytical model, the average degree of consolidation due to radial drainage $\left(U_{\mathrm{r}}\right)$ increases as the value of $a$ increases. Hence, for $a>0$, the equal strain hypothesis tends to underestimate the average degree of consolidation. The numerical prediction of the $\mathrm{Wu}$ and $\mathrm{Hu}$ (2012) axisymmetric model matches closely to different analytical models at different stages of consolidation (Figure 6). During consolidation, the strain distribution in the

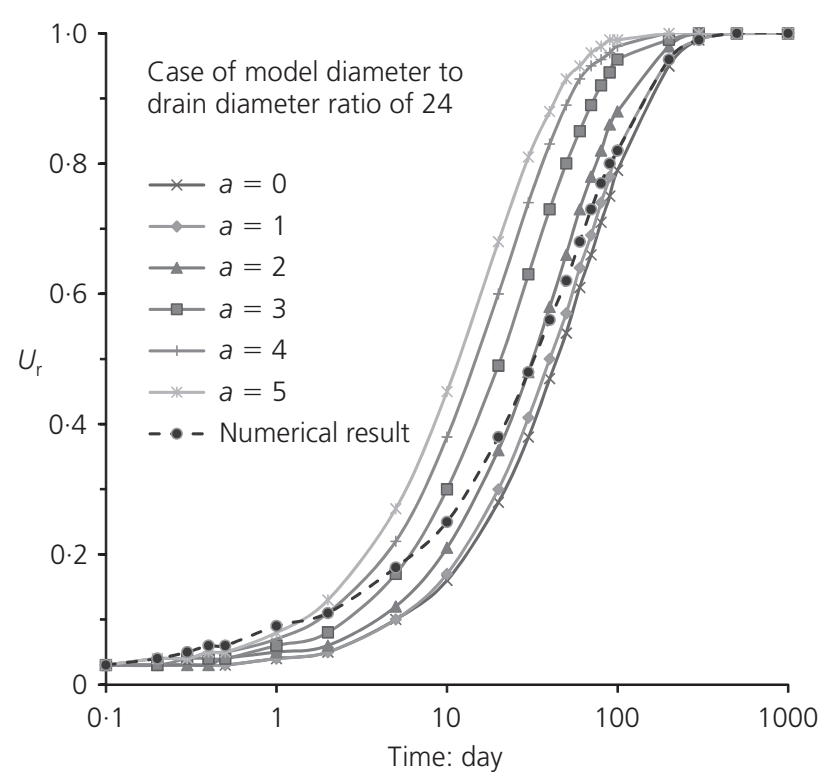

Figure 6. Comparison of average degree of radial consolidation against elapsed time plots produced by different analytical solutions and the numerical model (adapted from Wu and $\mathrm{Hu}$, 2012)

radial direction changes, becoming more uniform, such that the value of $a$ must decrease with elapsed time in order to correspond with the numerical result.

\section{Peat}

\subsection{Geotechnical properties}

Peat deposits are composed of the fragmented remains of dead plant vegetation that has accumulated under waterlogged conditions (Hobbs, 1986). Peat material ranges from fibrous, showing little or no humification, to highly humified (amorphous) peat having an almost granular appearance (O'Kelly and Pichan, 2013). Its in situ water content can vary greatly, from a few hundred per cent of dry mass to greater than $2000 \%$. An increase in fibre content creates a more open cellular structure, allowing greater water retention to occur in the pore voids and within the organic solids (Karunawardena, 2007). The botanical composition of peat also has an important influence on its engineering properties (Farrell et al., 2012).

Peat is considered as having among the poorest geotechnical properties of any foundation material (Dhowian and Edil, 1980). Heterogeneity and anisotropy usually mean that geotechnical and hydraulic properties can vary considerably within a peat deposit, even over short distances (Landva, 1980; O'Kelly and Pichan, 2013). Hence peat deposits present difficult ground conditions for building roads, dykes, housing developments, storage facilities, industrial parks, and so on, necessitating high initial (construction) costs and (or) frequent maintenance (Mesri and Ajlouni, 2007). They also generally have very low shear strength (typically 
$<15 \mathrm{kPa}$ ) and hence very low bearing capacity, undergoing large consolidation and creep settlements under loading. Relatively small and localised increases in effective stress, either due to an applied surface load and (or) reduction in groundwater level, can impact over a wide area (O'Kelly, 2009). Geotechnical instability can occur during construction of earthen embankments on peat deposits if appropriate ground improvement measures are not adopted. Some particular challenges can be seen, for example, from recent failures of peat dykes at Wilnis, The Netherlands (van Baars, 2005), canal embankments at Edenderry, Ireland (Pigott et al., 1992), peat bunds and dams at Raheenmore bog, Ireland (McInerney et al., 2006; O'Kelly, 2008) and also excessive deformation in road sub-base/subgrade causing serviceability failure of pavements (Osorio et al., 2008). Often surcharging with PVDs is not adequate, particularly when dealing with deep peat deposits, since the time period required to achieve substantial completion of consolidation settlements can be excessive (Ariyarathna et al., 2010) and PVDs are unlikely to help in accelerating the secondary compression (creep) rate during preloading. Creep settlement is significant for peat, often accounting for the major portion of the overall settlement over the design life.

\subsubsection{Compressibility}

Conventional evaluation of 1D settlement under embankment loading based on the measured compression-time response may result in an overprediction of the primary consolidation component and underprediction of secondary compression, especially for fibrous peats (Gofar and Sutejo, 2007). Such approaches are generally based on the two-stage concept of consolidation, with the primary consolidation stage terminating at a clearly defined point and secondary compression continuing indefinitely (Mesri et al., 1997; Vermeer and Neher, 1999). The problem of identifying when primary consolidation is substantially complete can be resolved, to some extent, by measuring the degree of dissipation of excess pore water pressure. However, some researchers (Hobbs, 1986; Robinson, 2003; Yun Tae and Leroueil, 2001) have argued that in the case of peat and other highly organic soils, secondary compression occurs simultaneously during primary consolidation. A laboratory study by Gofar and Sutejo (2007) suggests that for fibrous peat, secondary compres- sion commences when primary consolidation has reached $65 \%$ completion. Hence the assumption of creep as a continuous process, commencing early on during the primary consolidation stage for peat, provides a more realistic approach to settlement predictions (Karunawardena, 2007). Other important considerations in settlement analysis are the large strain (deformation) response and significant changes in geomechanical parameter values under loading, even for a constant state of effective stress.

\subsubsection{Permeability}

Reductions in void ratio of peat under sustained loading can produce dramatic reductions in permeability. Peat tends to have relatively high permeability initially, comparable to fine sand, but its void ratio reduces significantly under modest loading such that its permeability becomes similar to that of soft intact clay (Wong et al., 2009). Peat, but particularly fibrous peat, tends to exhibit a high degree of permeability anisotropy. For instance, the ratio of the coefficient of permeability for the horizontal flow direction $\left(k_{\mathrm{h}}\right)$ to the vertical flow direction $\left(k_{\mathrm{v}}\right)$ typically ranges between 1.7 and 7.5 initially. However, after consolidation under a modest applied load, the value of $k_{\mathrm{h}} / k_{\mathrm{v}}$ ratio can be significantly greater on account of the general horizontal alignment of the constituent fibres (Cuddy, 1988).

\subsection{Field application}

The vacuum consolidation technique has been used quite extensively, especially for soft clay deposits (Table 1). However, it has taken rather longer for its application to peat and other extremely soft soil deposits, to such an extent that, at present, reliable predictions of post-construction settlements cannot be made for these deposits (Masse et al., 2001). Some physiochemical properties of the peat deposits where vacuum consolidation treatment has been applied are reported in Table 2.

\subsubsection{Trial embankments for Sri Lankan highway}

Vacuum consolidation treatment was applied to a highly compressible amorphous peat layer during a highway construction project in Sri Lanka (Ariyarathna et al., 2010). The construction and monitoring of four vacuum consolidation field trials are described by Karunawardena and Nithiwana (2009). The ground was improved by combining stage-constructed surcharge embankments,
Project location (reference)

\section{Water content:}

$\%$

$110-470$
$650-1350$

Ballydermot raised bog, Ireland

(Osorio et al., 2010; Osorio-Salas, 2012;

Pichan and O'Kelly, 2013)

Ambes, France (Cognon et al., 1994)

Sapporo, Japan (Hayashi et al., 2002)
$430-860$
$200-700$
Organic content:

$\%$

$60-70$
$93-98$

NR

$10-60$
NR

NR
$\mathrm{pH}$ von Post number

Table 2. Physiochemical properties of peat deposits prior to vacuum consolidation treatment 


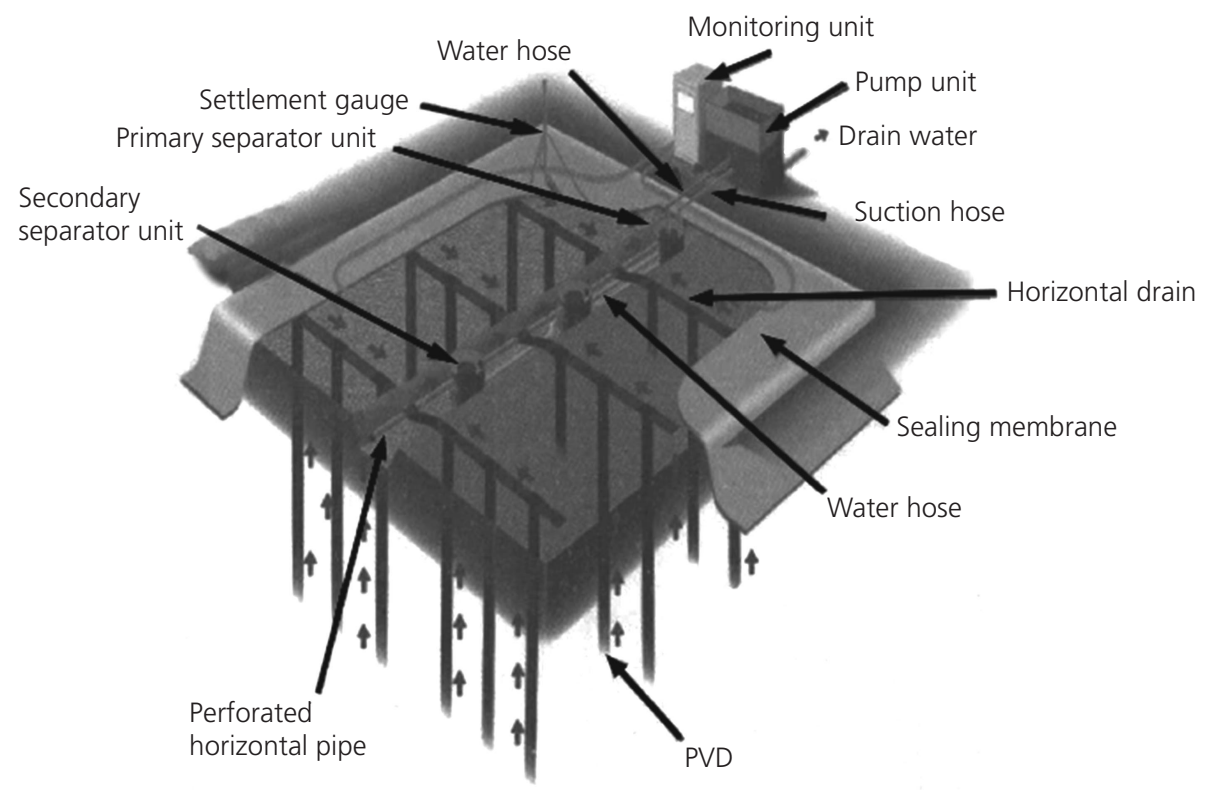

Figure 7. Schematic diagram of vacuum preloading set-up for Sri Lankan trial embankments (Ariyarathna et al., 2010). Reproduced by permission of The Institution of Engineers, Sri Lanka

on average $8 \mathrm{~m}$ high, with the vacuum consolidation technique. A schematic diagram of the set-up for the latter is shown in Figure 7. The PVDs were arranged in a square grid pattern at $1.0 \mathrm{~m}$ centre spacing. The peat layer, which extended from 4.7 to $7.7 \mathrm{~m}$ bgl, was underlain by loose to medium dense sand, with the groundwater table located close to the ground surface. As a general comment, in such a scenario, it is important to consider the reduction in surcharge loading that occurs due to partial submergence of the embankment following settlement of the ground surface.

Although the vacuum pump was supposed to generate suctions of approximately $90 \mathrm{kPa}$, the maximum vacuum pressure achieved was only $55 \mathrm{kPa}$, developed shortly after commencement of pumping. Hence an additional $2.5 \mathrm{~m}$ fill depth had to be added to the embankment surcharge. Under the average vacuum pressure of $35 \mathrm{kPa}$ actually achieved and final $10.5 \mathrm{~m}$ high embankment surcharge, the thickness of the $3 \mathrm{~m}$ deep peat layer was reduced by between $47 \%$ and $70 \%$ for the different trial areas. Note that for these very large strains, any rational assessment of the settlement response must be based on large strain theory. For three of the four trial areas, the average degree of consolidation predicted using the method proposed by Asaoka (1978) was in agreement with measured laboratory and field data, from which Ariyarathna et al. (2010) concluded that this method could be reliably applied to other Sri Lankan peaty deposits. The vacuumassisted surcharge trials also demonstrated that $95 \%$ of the total primary consolidation settlement could be achieved within an economically viable time period of approximately 8 months. However, adverse weather conditions and a shortage of fill material at the site location were cited as reasons for some delays. The measured undrained shear strength range of the peat layer was found to have increased from $7-33 \mathrm{kPa}$ initially to $38-79 \mathrm{kPa}$ after the treatment.

\subsubsection{Vacuum consolidation trial at the Ballydermot bog, Ireland}

A heavily instrumented vacuum consolidation trial was performed by Trinity College Dublin at the Ballydermot raised bog (County Offaly, Ireland), between November 2009 and October 2010, in order to investigate the feasibility of implementing this technique for use in road construction and widening of existing roads over peat deposits (Osorio et al., 2010; Osorio-Salas, 2012). The ground profile comprised a $4.0 \mathrm{~m}$ deep pseudo-fibrous peat layer (having a water content of $650-1350 \%$, reducing with depth), overlying glacial till deposits. Full details on the geotechnical and hydraulic properties of the test area have been reported by Osorio et al. (2010), Osorio-Salas (2012), Pichan and O'Kelly (2012) and O'Kelly and Pichan (2013). Figure 8 shows a schematic diagram of the vacuum consolidation set-up. The sealing membrane was secured at the bottom of a $1.0 \mathrm{~m}$ deep perimeter trench by backfilling with the excavated peat. This also had the effect of providing an airtight perimeter seal, with the natural groundwater table just outside the treatment area located at between $0 \cdot 25$ and $0.90 \mathrm{~m} \mathrm{bgl}$, depending on prevailing seasonal and climatic conditions. A peat layer approximately $0.5 \mathrm{~m}$ deep was placed directly over the sealing membrane to prevent damage caused by weathering, prolonged exposure to ultraviolet light and animals. The vacuum system initially incorporated a jet pump that produced a maximum suction of $80 \mathrm{kPa}$. However, this value could not be consistently achieved on account of chemical incrustation problems and hence a liquid-ring pump was used in 


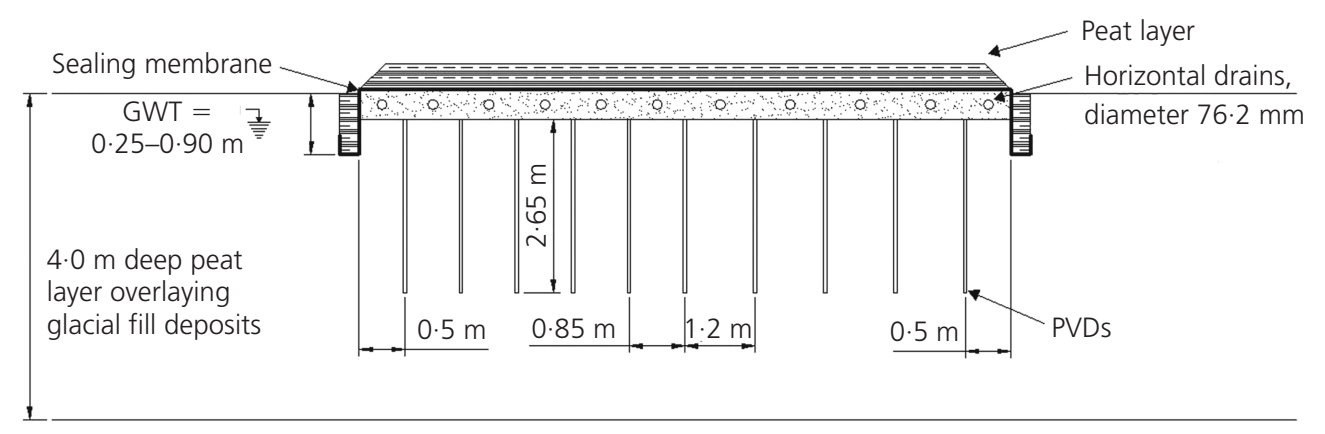

Figure 8. Cross-section of vacuum consolidation set-up for the

Ballydermot bog trial (Osorio et al., 2010)

combination with the jet pump to produce a more stable vacuum during the later stages of the trial. Over the course of the trial, the average suction achieved by the jet pump alone was $55 \mathrm{kPa}$, with suctions of between 52 and $71 \mathrm{kPa}$ achieved when used in combination with the liquid-ring pump.

Within the $10 \mathrm{~m} \times 10 \mathrm{~m}$ treatment area, two different PVD spacings were investigated, namely 0.85 and $1.20 \mathrm{~m}$. Both were installed in a square grid pattern to a depth of $2.65 \mathrm{~m} \mathrm{bgl}$ (i.e. partially penetrating the peat layer) in order to avoid connectivity with the underlying higher permeability glacial till layer. However, for these drain spacings, little difference was found in the measured settlement or excess pore water pressure by the end of the field trial. Maximum ground surface settlements achieved after vacuum pumping over an 11-month period were $1.09 \mathrm{~m}$ and $1.10 \mathrm{~m}$ for the sub-areas with PVD spacings of 0.85 and $1.2 \mathrm{~m}$, respectively $(\varepsilon \approx 27.5 \%$ ), with larger settlements occurring close to the centre of the test area on account of the large boundary effects. However, from data presented in Osorio et al. (2010), approximately $78 \%$ and $60 \%$ of the final measured settlement was achieved during the first 1-month vacuum period for the sub-areas having PVD spacing of 0.85 and $1.2 \mathrm{~m}$, respectively. This is to be expected since, in theory, the average degree of consolidation achieved is an inverse function of the effective drainage length.

Osorio-Salas (2012) described how a number of issues encountered during the trial may have been remedied. Considerable tension cracking around the perimeter of the test area on account of lateral inward displacement of the upper peat layer could have been reduced or potentially avoided by applying a suitable surcharge in combination with the vacuum. Vacuum pumping commenced during the winter months, and early on in the trial, the uppermost peat layer and groundwater froze due to inclement weather. The water inside the vacuum lines also froze periodically during this 11-week period, rendering the vacuum system inoperative. Adequate thermal protection applied to exposed hoses and pipes may have prevented freezing of the vacuum lines, allowing the system to remain in continuous service. A system of parallel pumps was also recommended so that vacuum application would not be interrupted should one pump fail or require maintenance. For instance, ferric incrustation occurring inside the pumps required periodic cessation of pumping operations in order to take appropriate remedial action.

\subsubsection{Other field applications}

Cognon et al. (1994) reported a vacuum-assisted preloading trial performed in Ambes, France, for the construction of a highway embankment over peat and highly organic clay deposits underlain by muddy sand. The $1.7 \mathrm{~m}$ deep peat layer, having a water content of $430-860 \%$, was underlain by a $2.0 \mathrm{~m}$ deep highly organic clay layer with a water content of $140-210 \%$. The trial comprised a two-stage embankment surcharge followed by vacuum preloading, with the settlement-time response shown in Figure 9. For the first stage, a $0.8 \mathrm{~m}$ deep sand blanket was placed on the ground surface, acting also as a drainage layer. After 3.5 weeks, PVDs were installed in a square grid pattern at $1.4 \mathrm{~m}$ spacing. After 5 weeks, the second surcharge layer, a $0.5 \mathrm{~m}$ deep granular bed, was placed. Vacuum pressure was applied from the beginning of week 7 . The $0.7 \mathrm{~m}$ settlement $(\varepsilon=18.9 \%)$ achieved for the initial $3.7 \mathrm{~m}$ depth of highly compressible material by the end of the 3 -month monitoring period was reported equivalent to that for a $4.5 \mathrm{~m}$ high embankment surcharge. An average degree of consolidation of $80 \%$ was achieved in the peat layer and $50 \%$ in the underlying organic clay. After removal of the vacuum, the ground surface heaved by $0.03 \mathrm{~m}$ within the first $48 \mathrm{~h}$, before stabilising. Based on the success of this trial, the vacuum consolidation technique was chosen over embankment surcharging as the better solution for preloading the highway foundations.

A point worth noting about the settlement response shown in Figure 9 is that the installation of the PVDs appeared to have no immediate or significant impact on the settlement rate. Referring to Figure 9, a plausible explanation is that primary consolidation settlement arising from the applied $0.8 \mathrm{~m}$ fill layer was already substantially complete. Hence, although greatly reducing the effective drainage length, PVD installation (without applying a vacuum pressure) did not significantly affect the settlement rate, since PVDs have no influence on the rate of secondary compression settlement. Another possibility observed for the Ballydermot bog trial (Osorio et al., 2010; Osorio-Salas, 2012) was that installation of the PVDs may cause some ground heave to occur 


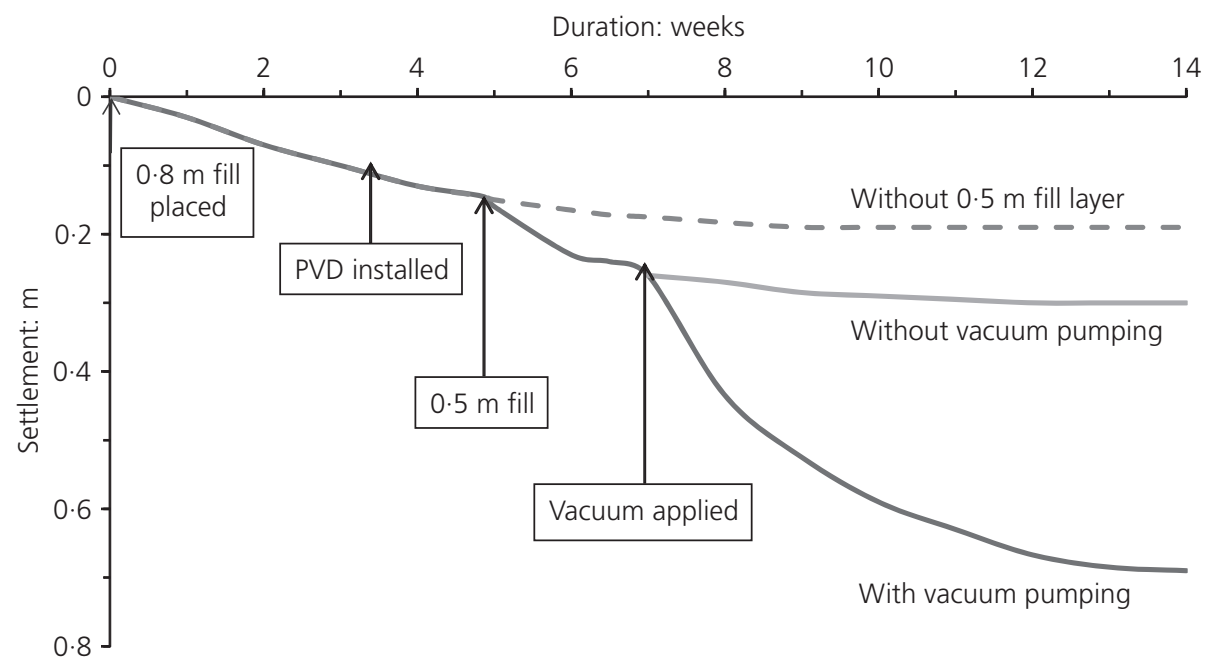

Figure 9. Settlement response for trial involving two-stage embankment surcharge followed by vacuum preloading in Ambes, France (adapted from Cognon et al., 1994)

on account of (sub) artesian pressure in underlying deposits. This may have essentially cancelled any increase in consolidation rate arising from the reduced effective draining length.

Hayashi et al. (2002) reported on vacuum-assisted preloading performed near Sapporo, Japan, for the construction of a highway embankment over fibrous peat deposits (water content of $200-700 \%$ ) underlain by a clayey peat layer. PVDs were installed in a square grid pattern at $0.8 \mathrm{~m}$ spacing. Negative pressures achieved in the fibrous peat layer were $50 \mathrm{kPa}$, close to the design suction of $60 \mathrm{kPa}$. However, vacuum pressures of only $20 \mathrm{kPa}$ were measured in underlying deposits. The settlement responses of the underlying layers were also delayed relative to the fibrous peat deposit. It was found that the consolidation rate was very sensitive to PVD spacing, from which Hayashi et al. (2002) concluded that significant ground improvement could not be achieved for PVD spacing greater than $0.9 \mathrm{~m}$. In practice, however, minimum spacing is more relevant as a design guide since too close a spacing may result in overlapping of smear zones, causing a decrease in the consolidation rate.

The apparent conflict between the Ballydermot bog trial (Osorio et al., 2010; Osorio-Salas, 2012) and large-scale vacuum-assisted preloading works near Sapporo (Hayashi et al., 2002) regarding suitable PVD spacing for successful application of the technique illustrates the difficulties in comparing projects on different types of peat. If nothing else, the general success of these projects demonstrates that the vacuum consolidation technique can be applied just as effectively for peaty soils as for soft clay deposits, where the technique has been widely applied. Each project described above was justified in testing the feasibility of using vacuum preloading as a viable ground improvement method for peat deposits. The most salient matter to consider when testing the effectiveness of the technique in peat deposits is the extent of the residual settlements. Secondary compression settlements anticipated over the design life of the structure can be reduced to acceptable levels by sufficiently increasing the OCR of the bearing strata. This was demonstrated, for example, at the vacuum-consolidated Sri Lankan highway site (Ariyarathna et al., 2010).

\section{Recommendations for further research}

To date, the majority of vacuum consolidation projects have been performed on soft clayey soils, although a number of field projects have also involved improvement of peaty soils. There is significant scope for performing further experimental and numerical studies on the behaviour of peat in response to vacuum preloading, particularly towards addressing the following issues.

- Is the settlement rate during the secondary compression stage different for vacuum-assisted preloading than an equivalent embankment surcharge? Applied loading causes rupture to the fibrous peat structure (Mesri and Ajlouni, 2007) and structural rearrangement of the solid particles (Hobbs, 1986; O'Kelly, 2013) such that more water is released from micropores within the organic solids (Berry and Poskitt, 1972; Hobbs, 1986) out to the macropores (i.e. the pore void space between the solid particles) after secondary compression commences. The additional pore water expelled from the micropores on account of the particle rupture may possibly drain more quickly with the aid of vacuum-assisted preloading than for surcharging alone, as has been observed by Saowapakpiboon et al. $(2010,2011)$ for the primary consolidation stage. Field testing would require many years to adequately investigate the secondary compression responses. However, using physical models, such an investigation could be performed in a much shorter timeframe. Furthermore, the controlled stress, boundary and drainage conditions that 
laboratory testing can offer would allow more definitive comparisons of the long-term deformation response of peat under different applied vacuum and (or) surcharge preloading scenarios.

- During vacuum consolidation, is inward lateral displacement of the uppermost layer likely to be greater for peat on account of its very high compressibility? According to Ong and Chai (2011), the amount of lateral displacement not only depends on the loading condition and magnitude but also on the consolidation and deformation characteristics of the soil. This is supported by the empirical relationship between horizontal and vertical displacement developed by Mesri and Khan (2012).

- Does the same ratio of vacuum pressure to embankment surcharge stress produce the same net lateral displacement against depth for soft clays and peat deposits? A specialised large-scale apparatus based, for example, around the operating principles of the hydraulic consolidation (Rowe cell) apparatus could be developed and used to investigate relative lateral deformations experienced by peat and soft clay test specimens under the same loading and drainage conditions. Also, the combination of surcharge stress and vacuum pressure necessary to prevent any lateral deformation from occurring could be investigated.

- Are smear effects and well resistance greater for peat than soft mineral soils? Fibrous peat generally has a very high initial permeability, although within the smear zone, this reduces dramatically under remoulding during PVD installation. Hence, it may follow that the $k_{\mathrm{h}} / k_{\mathrm{S}}$ ratio will be larger for fibrous peats than soft clays.

- Can the PVD installation depth be systematically reduced, and by what amount, in moving closer to the centre of the treatment area while still achieving just as effective but more economical results than the same PVD installation depth applied across the entire test area.

- There is also a dearth of knowledge regarding the relationship between OCR achieved under different applied vacuum and (or) surcharge preloading and subsequent creep settlements under embankment loading.

\section{Summary and conclusions}

Much research has been performed on the response of soft clays to vacuum preloading, giving rise to a better understanding and the development of new laboratory apparatus and analytical models in the process. As the technology has matured, the benefits of vacuum consolidation over other forms of ground improvement have become clearer and are now widely accepted. The main issue around improving settlement predictions has been in relation to evaluating the effect of soil disturbance arising from PVD installation on the overall performance of the vacuum consolidation system. Recent improvements in numerical simulations have included modelling of non-Darcian flow conditions, non-linear soil properties and the radius-related strain distribution method. A plane-strain analysis is usually adequate for modelling PVD arrays in ground under treatment and can be readily integrated within numerical analysis. Hence, numerical models have achieved improved accuracy, although some remaining discrepancies between numerical predictions and field measurements for vacuum-assisted preloading require further attention. These discrepancies arise from difficulties in predicting factors relating to PVD installation (smear and well resistance) in addition to incorrect assumptions regarding soil behaviour and the vacuum pressure distribution achievable.

Vacuum-assisted consolidation is now widely accepted as a useful and practical technique for reducing post-construction settlement. However, to date, only a handful of investigations, most of which are limited to field trials, have considered its use in peat and other highly organic soil deposits. These investigations have demonstrated that the technique can be successfully applied for such difficult ground conditions, although the ground response may be markedly different from that observed for soft clays. In the case of highly compressible deposits including peat, large settlements developed under vacuum consolidation may result in significant lateral inward displacement occurring in the uppermost layers. By combining surcharge and vacuum loading techniques, net lateral displacements can be approximately controlled for certain design applications. The secondary compression response of peat under different applied vacuum and (or) surcharge preloading scenarios also merits further investigation.

\section{Acknowledgements}

The first writer kindly acknowledges a Postgraduate Research Scholarship Award from Trinity College Dublin. The writers also thank the reviewers for many helpful comments.

\section{REFERENCES}

Ariyarathna PRC, Thilakasiri HS and Karunawardena WA (2010)

Vacuum consolidation of Sri Lankan peaty soil. Annual Transactions of The Institution of Engineers, Sri Lanka, pp. 27-37.

Asaoka A (1978) Observational procedure of settlement prediction. Soils and Foundations 18(4): 87-101.

Beales SP and O'Kelly BC (2008) Performance of embankments on soft ground: A1033 Hedon Road Improvement Scheme, UK. Proceedings of the 1st International Conference on Transportation Geotechnics, Nottingham, UK, (Ellis E, Yu H-S, McDowell G, Dawson AR and Thom N (eds.)), CRC Press/Balkema, Leiden, Netherlands, Vol. 1, pp. 369-375.

Bergado DT, Asakami H, Alfaro MC and Balasubramaniam AS (1991) Smear effects of vertical drains on soft Bangkok clay. Journal of Geotechnical Engineering, ASCE 117(10): 15091530.

Bergado DT, Chai JC, Miura N and Balasubramaniam AS (1998)

PVD improvement of soft Bangkok clay with combined vacuum and reduced sand embankment preloading. Proceedings of the Institution of Civil Engineers Geotechnical Engineering 29(1): 95-122.

Berry PL and Poskitt TJ (1972) The consolidation of peat. Géotechnique 22(1): 27-52. 
Bo MW, Bawajee R and Choa V (1998) Smear effect due to mandrel penetration. Proceedings of the 2nd International Conference on Ground Improvement Techniques, Singapore. CI Premier, Singapore, pp. 83-92.

Bo MW, Chu J, Low BK and Choa V (2003) Soil Improvement: Prefabricated Vertical Drain Techniques. Thomson Learning, Singapore.

Chai J, Hong Z and Shen S (2010) Vacuum-drain consolidation induced pressure distribution and ground deformation. Geotextiles and Geomembranes 28(6): 525-535.

Chai J, Miura N and Bergado DT (2008) Preloading clayey deposit by vacuum pressure with cap-drain: analyses versus performance. Geotextiles and Geomembranes 26(3): 220230

Chai JC, Carter JP and Hayashi S (2005) Ground deformation induced by vacuum consolidation. Journal of Geotechnical and Geoenvironmental Engineering 131(12): 1552-1561.

Chai JC, Hayashi S and Carter JP (2006) Vacuum consolidation and its combination with embankment loading. Canadian Geotechnical Journal 43(10): 177-184.

Chai JC, Miura N, Kirekawa T and Hino T (2009) Optimum PVD installation depth for two-way drainage deposit. Geomechanics and Engineering, An International Journal 1(3): 179-192.

Choa V (1989) Drains and vacuum preloading pilot test. Proceedings of the 12th International Conference on Soil Mechanics and Foundation Engineering, Rio de Janeiro, Brazil, Taylor and Francis Group, London, UK, pp. $1347-$ 1350.

Chu J and Yan SW (2005a) Application of the vacumm preloading method in soil improvement projects. In Ground Improvement - Case histories, Elsevier Geo-Engineering Book Series (Indraratna B and Chu J (eds.)), Elsevier, London, UK, Vol. 3, pp. 91-117.

Chu J and Yan SW (2005b) Estimation of degree of consolidation for vacuum preloading projects. International Journal of Geomechanics 5(2): 158-165.

Chu J, Yan SW and Yang H (2000) Soil improvement by the vacuum preloading method for an oil storage station. Géotechnique 50(6): 625-632.

Chu J, Yan S and Indraranata B (2008) Vacuum preloading techniques - recent developments and applications. In Proceedings of ASCE GeoCongress: Geosustainability and Geohazard Mitigation, New Orleans (Reddy KR, Khire MV and Alshawabkeh AN (eds)). ASCE, Reston, VA, USA, pp. $586-595$.

Cognon JM, Juran I and Thevanayagam S (1994) Vacuum consolidation technology - principles and field experience. Proceedings of the Conference on Vertical and Horizontal Deformations of Foundations and Embankments, College Station, TX, USA, (Yeung AT and Felio GY (eds.)). ASCE, New York, NY, USA, Geotechnical Special Publication 40, pp. $1237-1248$.

Cuddy T (1988) The Behaviour of Bog Road Pavements. Masters thesis, University of Dublin, Trinity College, Dublin, Ireland.
Dam LTK, Sandanbata I and Kimura M (2006) Vacuum Consolidation Method - Worldwide Practice and the Latest Improvement in Japan. Hazama Corporation, Japan, Technical Research Report.

Deng YB, Xie KH, Lu MM, Tao HB and Liu GB (2013) Consolidation by prefabricated vertical drains considering the time dependent well resistance. Geotextiles and Geomembranes 36(1): 20-26.

Dhowian AW and Edil TB (1980) Consolidation behaviour of peats. Geotechnical Testing Journal 3(3): 105-114.

Farrell ER, O'Kelly BC and Osorio Salas JP (2012) Vacuum Consolidation in Peat. Invited Continuing Professional Development Lecture to the Geotechnical Society of Ireland. Engineers Ireland, Dublin, Ireland.

Geng X, Indraratna B, Rujikiatkamjorn C and Kelly R (2012) Non-linear analysis of soft ground consolidation at the Ballina bypass. In Proceedings of the 11th Australia-New Zealand Conference on Geomechanics: Ground Engineering in a Changing World 2012 (Narsilio GA, Arulrajah A and Kodikara J (eds)). Engineers Australia, Australia, pp. 197202.

Ghandeharioon A, Indraratna B and Rujikiatkamjorn C (2010) Analysis of soil disturbance associated with mandrel-driven prefabricated vertical drains using an elliptical cavity expansion theory. International Journal of Geomechanics 10(2): 53-64.

Ghandeharioon A, Indraratna B and Rujikiatkamjorn C (2012) Laboratory and finite-element investigation of soil disturbance associated with the installation of mandrel-driven prefabricated vertical drains. Journal of Geotechnical and Geoenvironmental Engineering 138(3): 295-308.

Gofar N and Sutejo Y (2007) Long term compression behaviour of fibrous peat. Malaysian Journal of Civil Engineering 19(2): 104-116.

Hansbo S, Jamiolkowski M and Kok L (1981) Consolidation by vertical drains. Géotechnique 31(1): 45-66.

Hayashi H, Nishikawa J and Sawai K (2002) Improvement effect of vacuum consolidation and prefabricated vertical drains in peat ground. Proceedings of the 4th International Conference on Ground Improvement Techniques, Kuala Lumpur, Malaysia, CI Premier, Singapore, pp. 391-398.

Hobbs NB (1986) Mire morphology and the properties and behaviour of some British and foreign peats. Quarterly Journal of Engineering Geology 19(1): 7-80.

Indraratna B (2010) Recent advances in the application of vertical drains and vacuum preloading in soft soil stabilisation. Australian Geomechanics Journal 45(2): 1-44.

Indraratna B and Redana IW (2000) Numerical modeling of vertical drains with smear and well resistance installed in soft clay. Canadian Geotechnical Journal 37(1): 132-145.

Indraratna B and Rujikiatkamjorn C (2008) Effects of partially penetrating prefabricated vertical drains and loading patterns on vacuum consolidation. Proceedings of $A S C E$ GeoCongress: Geosustainability and Geohazard Mitigation, New Orleans, ASCE, Reston, VA, USA, pp. 596-603. 
Indraratna B, Bamunawita C and Khabbaz H (2004) Numerical modeling of vacuum preloading and field applications. Canadian Geotechnical Journal 41(6): 1098-1110.

Indraratna B, Sathananthan I, Rujikiatkamjorn C and Balasubramaniam AS (2005) Analytical and numerical modeling of soft soil stabilized by prefabricated vertical drains incorporating vacuum preloading. International Journal of Geomechanics 5(2): 114-124.

Indraratna B, Geng X and Rujikiatkamjorn C (2010a) Review of methods of analysis for the use of vacuum preloading and vertical drains for soft clay improvement. Geomechanics and Geoengineering 5(4): 223-236.

Indraratna B, Rujikiatkamjorn C, Kelly R and Buys H (2010b) Soft soil foundation improved by vacuum and surcharge preloading at Ballina bypass, Australia. Proceedings of International Symposium on Ground Improvement Technologies and Case Histories, Singapore, pp. 95-105.

Indraratna B, Rujikiatkamjorn C, Kelly R and Buys H (2010c) Sustainable soil improvement via vacuum preloading. Proceedings of the Institution of Civil Engineers - Ground Improvement 163(1): 31-42.

Indraratna B, Rujikiatkamjorn C, Ameratunga J and Boyle P (2011) Performance and prediction of vacuum combined surcharge consolidation at Port of Brisbane. Journal of Geotechnical and Geoenvironmental Engineering 137(11): 1009-1018.

Indraratna B, Rujikiatkamjorn C, Balasubramaniam AS and Mcintosh G (2012a) Soft ground improvement via vertical drains and vacuum assisted preloading. Geotextiles and Geomembranes 30(1): 16-23.

Indraratna B, Rujikiatkamjorn C and Geng X (2012b) Performance and prediction of surcharge and vacuum consolidation via prefabricated vertical drains with special reference to highways, railways and ports. In Proceedings of International Symposium on Ground Improvement (Denies $\mathrm{N}$ and Huybrechts N (eds)). ISSMGE, Brussels, Belgium, Vol. 2, pp. 145-168.

Karunawardena A and Nithiwana W (2009) Construction of a trial embankment on peaty ground using vacuum consolidation method for a highway construction project in Sri Lanka. Proceedings of 7th International Conference on Soil Mechanics and Geotechnical Engineering, Alexandria, Egypt, pp. 2200-2203.

Karunawardena WA (2007) Consolidation Analysis of Sri Lankan Peaty Clay Using Elasto-viscoplastic Theory. $\mathrm{PhD}$ thesis, Kyoto University, Kyoto, Japan.

Kim R, Hong SJ, Lee MJ and Lee W (2011) Time dependent well resistance factor of PVD. Marine Georesources and Geotechnology 29(2): 131-144.

Kjellman W (1952) Consolidation of clay soil by means of atmospheric pressure. Proceedings of a Conference on Soil Stabilization, Massachusetts Institute of Technology, Boston, pp. 258-263.

Landva AO (1980) Geotechnical Behaviour and Testing Peat. Thesis, University of Laval, Quebec, Canada.
Masse F, Spaulding CA, Wong IC and Varaksin S (2001) Vacuum consolidation: a review of 12 years of successful development. In Proceedings of 2001: A Geo-Odyssey (Brandon TL (ed.)). Virginia Polytechnic Institute and State University, Blacksburg, Virginia, USA, pp. 1-23.

McInerney GP, O'Kelly BC and Johnston PM (2006) Geotechnical aspects of peat dams on bog land. Proceedings of the 5th International Congress on Environmental Geotechnics, Cardiff, UK, Thomas Telford, London, UK, Vol. 2, pp. 934-941.

Mesri G and Ajlouni M (2007) Engineering properties of fibrous peats. Journal of Geotechnical and Geoenvironmental Engineering 133(7): 850-866.

Mesri G and Khan AQ (2012) Ground improvement using vacuum loading together with vertical drains. Journal of Geotechnical and Geoenvironmental Engineering 138(6): 680-689.

Mesri G, Stark TD, Ajlouni MA and Chen CS (1997) Secondary compression of peat with or without surcharging. ASCE Journal of Geotechnical Engineering 123(5): 411-420.

Mohamedelhassan E and Shang JQ (2002) Vacuum and surcharge combined one-dimensional consolidation of clay soils. Canadian Geotechnical Journal 39(5): 1126-1138.

O'Kelly BC (2008) On the geotechnical design and use of peat bunds in the conservation of bogs. In Proceedings of the 1st International Conference on Geotechnical Engineering, Hammamet, Tunisia, (Bouassida M, Romdhane NB and Hamdi E (eds.)), Sfax, Tunisie, Vol. 1, pp. 259-267.

O'Kelly BC (2009) Development of a large consolidometer apparatus for testing peat and other highly organic soils. SUO - Mires and Peat 60(1-2): 23-36.

O'Kelly BC (2013) Characterisation of undrained strength of amorphous clay. In Proceedings of the Institution of Civil Engineers - Geotechnical Engineering, in press. See http:// dx. doi.org/10.1680/geng.11.00025.

O'Kelly BC and Pichan SP (2013) Effect of decomposition on the compressibility of fibrous peat - a review. Geomechanics and Geoengineering, in press, see http://dx.doi.org/DOI:10.1080/ 17486025.2013 .804210$.

Ong CY and Chai JC (2011) Lateral displacement of soft ground under vacuum pressure and surcharge load. Frontiers of Architecture and Civil Engineering in China 5(2): 239-248.

Ong CY, Chai JC and Hino T (2012) Degree of consolidation of clayey deposit with partially penetrating vertical drains. Geotextiles and Geomembranes 34(5): 19-27.

Osorio-Salas JP (2012) Vacuum Consolidation Field Test on a Pseudo-fibrous Peat. PhD thesis, University of Dublin, Trinity College, Dublin, Ireland.

Osorio JP, Farrell ER, O'Kelly BC and Casey T (2008) Rampart roads in the peat lands of Ireland: genesis, development and current performance. Proceedings of the 1st International Conference on Transportation Geotechnics, Nottingham, UK, CRC Press/Balkema, Leiden, the Netherlands, Vol. 1, pp. 227-233.

Osorio JP, Farrell ER and O'Kelly BC (2010) Peat improvement 
under vacuum preloading: A novel approach for bog roads in Ireland. Proceedings of the Joint Symposium on Bridge and Infrastructure Research in Ireland and Concrete Research in Ireland (BCRI 2010), Cork, Ireland, pp. 255-262.

Pichan SP and O'Kelly BC (2012) Effect of decomposition on the compressibility of fibrous peat. Proceedings of ASCE GeoCongress 2012: State of the Art and Practice in Geotechnical Engineering, Oakland, California, USA, ASCE, Reston, VA, USA, Geotechnical Special Publication 225, pp. 4329-4338.

Pichan SP and O'Kelly BC (2013) Stimulated decomposition in peat for engineering applications. Proceedings of the Institution of Civil Engineers - Ground Improvement 166(3): 168-176, see http://dx.doi.org/DOI:10.1680/grim.12.00003.

Pigott PT, Hanrahan ET and Somers N (1992) Major canal reconstruction in peat. Proceedings of the Institution of Civil Engineers - Water Maritime and Energy 96(3): 141-152.

Qian JH, Zhao WB, Cheung YK and Lee PKK (1992) The theory and practice of vacuum preloading. Computers and Geotechnics 13(2): 103-118.

Qiu QC, Mo HH and Dong ZL (2007) Vacuum pressure distribution and pore pressure variation in ground improved by vacuum preloading. Canadian Geotechnical Journal 44(12): 1433-1445.

Robinson RG (2003) A study on the beginning of secondary compression of soils. Journal of Testing and Evaluation 31(5): 388-397.

Robinson RG, Indraratna B and Rujikiatkamjorn C (2012) Final state of soils under vacuum preloading. Canadian Geotechnical Journal 49(6): 729-739.

Rujikiatkamjorn C and Indraratna B (2007) Analytical solutions and design curves for vacuum-assisted consolidation with both vertical and horizontal drainage. Canadian Geotechnical Journal 44(2): 188-200.

Saowapakpiboon J, Bergado DT, Youwai S et al. (2010) Measured and predicted performance of prefabricated vertical drains (PVDs) with and without vacuum preloading. Geotextiles and Geomembranes 28(1): 1-11.

Saowapakpiboon J, Bergado DT, Voottipruex P, Lam LG and Nakakuma K (2011) PVD improvement combined with surcharge and vacuum preloading including simulations. Geotextiles and Geomembranes 29(1): 74-82.

Sathananthan I and Indraratna B (2006) Laboratory evaluation of smear zone and correlation between permeability and moisture content. Journal of Geotechnical and Geoenvironmental Engineering 132(7): 942-945.

Seah TH (2006) Design and construction of ground improvement works at Suvarnabhumi airport. Geotechnical Engineering, Journal of the Southeast Asian Geotechnical Society 37(3): $171-188$.

Sharma JS and Xiao D (2000) Characterization of a smear zone around vertical drains by large-scale laboratory tests. Canadian Geotechnical Journal 37(6): 1265-1271.

Shiono T, Nakakuma K, Kubo M et al. (2001) Stabilization of embankment on compact vacuum consolidation. Proceedings of the 15th International Conference on Soil Mechanics and Geotechnical Engineering, Istanbul, Turkey, pp. 1847-1850. Taylor \& Francis.

TPEI (Tianjin Port Engineering Institute) (1995) Vacuum Preloading Method to Improve Soft Soils and Case Studies. Tianjin Port Engineering Institute, Tianjin, China.

Tran TA and Mitachi T (2008) Equivalent plane strain modeling of vertical drains in soft ground under embankment combined with vacuum preloading. Computers and Geotechnics 35(5): 655-672.

van Baars S (2005) The horizontal failure mechanism of the Wilnis peat dyke. Géotechnique 55(4): 319-323.

Vermeer PA and Neher HP (1999) A soft soil model that accounts for creep. Proceedings of the International Symposium, Beyond 2000 in Computational Geotechnics - Ten Years of PLAXIS International, Amsterdam, pp. 249-261. Balkema, Rotterdam, The Netherlands.

Walker R and Indraratna B (2009) Consolidation analysis of a stratified soil with vertical and horizontal drainage using the spectral method. Géotechnique 59(5): 439-449.

Wong LS, Hashim R and Ali FH (2009) A review on hydraulic conductivity and compressibility of peat. Journal of Applied Sciences 9(18): 3207-3218.

Wu H and Hu L (2012) Analytical and numerical solutions for vacuum preloading considering a radius related strain distribution. Mechanics Research Communications 44: 9-14.

Yan SW and Chu J (2003) Soil improvement for a road using the vacuum preloading method. Proceedings of the Institution of Civil Engineers - Ground Improvement 7(4): 165-172.

Yan SW and Chu J (2005) Soil improvement for a storage yard using the combined vacuum and fill preloading method. Canadian Geotechnical Journal 42(4): 1094-1104.

Yun Tae K and Leroueil S (2001) Modeling the viscoplastic behaviour of clays during consolidation: Application to Berthierville clay in both laboratory and field conditions. Canadian Geotechnical Journal 38(3): 484-497.

\section{WHAT DO YOU THINK?}

To discuss this paper, please email up to 500 words to the editor at journals@ice.org.uk. Your contribution will be forwarded to the author(s) for a reply and, if considered appropriate by the editorial panel, will be published as a discussion in a future issue of the journal.

Proceedings journals rely entirely on contributions sent in by civil engineering professionals, academics and students. Papers should be 2000-5000 words long (briefing papers should be 1000-2000 words long), with adequate illustrations and references. You can submit your paper online via www.icevirtuallibrary.com/content/journals, where you will also find detailed author guidelines. 